\author{
A. Bainiazov $^{1}$, M.A. Maretbayeva ${ }^{2}$, Sh.Sh. Zhalmakhanov ${ }^{2}$, M. Dzhusupov ${ }^{3}$ \\ ${ }^{1}$ Ardachan university, Turkey; \\ ${ }^{2}$ Medical university Karaganda, Kazakhstan; \\ ${ }^{3}$ Academy of Siences, Uzbekiston \\ (E-mail:aiabek-1967@mail.ru)
}

\title{
Phono-morpho-lexical similarity of auxiliary morphemes of the dictionary «Mukaddimat al-adab» (XIII century) Az-Zamakhshari with the Kazakh language
}

\begin{abstract}
The article provides a linguistic and historical overview of the problem of integration and differentiation of kinship and affinity of languages, including the features of unions. Based on the conducted linguistic analysis, the authors come to the conclusion that if adverbs in languages of different genders and tribes of Turkic origin are the result of integration of Turkic languages, then the division in the middle ages of Turkic languages (modern national languages, such as Kazakh, Kyrgyz, Uzbek, etc. languages) is the result of the division of Turkic languages into branches, groups and subgroups. In the course of the work, the authors identify integration and differentiation processes, the kinship and affinity of languages and their integration into one language union, which was influenced by extralinguistic factors. Analysis and comparison of homonymous and polysemantic auxiliary morphemes, namely: case endings, plural endings, possessiveness and declension, suffixes of the noun, adjective, pronouns and verbs of the az-Zamakhshari dictionary [1] and the Kazakh language once again proves the historical uniformity of the vocabulary of the XII century and the modern Kazakh language. At the end of the article, the authors conclude that the differences between auxiliary morphemes in the «Dictionary» and the Kazakh language are expressed in phonetic composition, and semantic and grammatical functions of morphemes state the similarity and homogeneity of languages that belong to the Kipchak, Oguz and Karluk groups.
\end{abstract}

Keywords: integration and differentiation of languages, internal and external factors, main criteria for determining language affinity, auxiliary morphemes, Kipchak, Karluk, Oguz and Bulgar groups of Turkic languages.

Problems of integration and differentiation of languages, internal and external factors affecting their formation and development, issues of kinship and affinity of languages in the history of linguistics have been studied in depth. Linguistic studies on the problems we have been considering at the end of the 19th and early 20th centuries were conducted on the basis of French, German, Spanish, Icelandic, Italian and Russian languages (R. Rask, V. Pizani, G. Shukhardt, I. Shtidt, I. Buslaev, N.Ya.Marr) [2; 3]. As a result of the studies, it was found that geographically closely located languages can be similar based on two types of proximity: kinship of languages and affinity of languages. Thus, kindred languages are those in which the sound composition, ancient roots and affixes, grammatical forms and their changes, which are the means of communication of related tribes and peoples, are common. About forty Turkic dialects and languages that exist in the world are proof of this. In turn, the kinship of languages is facilitated by the neighboring and mixed location of several peoples, as a result of which common features appear at different levels of the language, which is confirmed by the existence of several language unions in the modern world. At the dawn of the history of linguistics as a science, there was a statement about the formation of the Balkan languages Union (Greek, Albanian, Bulgarian, Romanian, Macedonian languages). Over the past three decades, theories of the existence of several language unions have appeared in the science of language - about ten, among them: the European language Union, the Volga language Union, the IranianIraqi language Union (this includes the South Caucasian languages, the languages of Eastern Turkey, Northern Iraq, and Northern Iran).

The authors believe that the ideas expressed in the presented scientific and theoretical researches are primarily associated with the medieval language related to the Turkic languages. In this regard, the statement that only unrelated languages belong to the language Union loses its relevance. The medieval languages of the Turkic tribes are the result of integration, while the modern individual Turkic languages are the result of differentiation. Consistently analyzed by the authors of the article materials of the dictionary 
«Mukaddimat al-adab» Zamakhshari allow us to assert that its content is an indicator of the integration era, and modern Turkic languages - of the differentiation era.

The main purpose of comparisons and contrasts of a particular language with other languages and materials of written monuments makes it possible to determine the reason for the relationship and correlation of kindred or not kindred languages or written monuments, which can become the basis of evidence-based characteristics of languages from the point of view of their kinship or affinity.

To determine the genological relationship of one language with other languages, one written monument with other monuments, or the relationship of a particular language with a written monument, we mainly use descriptive, diachronic, and typological methods that allow us to compare and contrast the phonetic, lexical, and grammatical units of languages (monuments).

Determining the genetic and kinship affinity of languages (monuments), Rasmus Rask in his work «the Origin of the Icelandic language» noted that «in the knowledge of the origin of peoples and their kinship with other peoples, there is no better tool than language. And in comparative research, grammar is a reliable part of the language, because words can be borrowed, and the affixes of declension and case endings do not change or borrow even between related languages» $[2 ; 3 ; 4 ; 5]$. Based on the statement of one of the founders of comparative historical linguistics, we use auxiliary morphemes of the Zamakhshari dictionary and the modern Kazakh language to determine historical proximity. This is primarily due to the fact that the sound and lexical composition of languages can change and be borrowed under the influence of extralinguistic factors, while endings and suffixes remain unchanged. In this regard, as a material for analysis, we select the general auxiliary affixes of words presented in the dictionary and words of the modern Kazakh language, and by comparing and contrasting them, we determine the similarities and features. We believe that the similarity of auxiliary morphemes can be explained by the fact that the languages of the Turkic tribes still did not reach the level of full differentiation in the XIII-XIV centuries. We will try to prove this assumption by analyzing the actual material of our study, i.e. auxiliary affixes.

As it's known comparatively, the historical analysis of language units is carried out as a result of the use of such methods as external reconstruction, typological modification and language universals. Accordingly, for the purpose of research, the tools of the above methods are used when parsing words from the position of phono-morpho-lexical aspects. So, using the traditional classification, we ungrouped auxiliary morphemes into endings and suffixes, the endings in turn were classified into plural endings, case endings, personal endings and endings of possessiveness, suffixes - into word-forming and form-forming ones, and equally sounding affixes - into polysemy and homonymy.

The Zamakhshari dictionary «Muqaddimat al-adab» has only 224 suffixes, of which only 111 are active in the modern Kazakh language. The preservation of almost half of the auxiliary grammatical forms in the modern Kazakh language is, in our opinion, a proof of the historical homogeneity of the research objects.

As a result of phono-morpho-lexical comparison and juxtaposition of auxiliary morphemes of the Zamakhshari dictionary and the modern Kazakh language, the number of auxiliary morphemes (grammatical forms) and the quality (grammatical meanings) of auxiliary morphemes are determined. So, on the one hand, there are more grammatical meanings of morphemes in modern Turkic languages, including the Kazakh language, than when the dictionary was compiled, which is explained by the enrichment of the vocabulary and the composition of the language in a meaningful way, due to the development of socio-economic, cultural and political life of native speakers. On the other hand, compared with the dictionary data in modern Turkic languages, including the Kazakh language, there are less grammatical forms of morphemes. In our opinion, this is due to factors such as the development of a written culture, the «grinding» of auxiliary morphemes duplicating each other, etc.

In addition, it is interesting, in our opinion, that auxiliary morphemes of the dictionary (monuments of writing of the middle ages in general) were divided by the phonological nature of joining the root of the word in modern Turkic languages, which is due to lingual and labial synharmonism and soft-hard assimilation.

An analysis of the features of auxiliary morphemes of the Zamakhshari dictionary and the modern Kazakh language allows us to consider them in such aspects: 1) personal endings, case endings, endings of possessiveness and plurality, 2) form-forming and word-forming suffixes.

From case endings in the dictionary there are endings:

- of genitive case: -dyń, -nyń, -niń;

- of outgoing case: -da,-de. 
The endings of the original case -dan, - men, as well as the endings of the prepositional case of the modern Kazakh language are not found in the dictionary at all.

The plural endings -lar, - ler are available in both comparable materials.

The dictionary also contains personal endings of the I person -m,-ym,-im, of the II person -yn,-in, of the III person -dy,-di,-ty,-ti, plural form of the III person -imiz of the Kazakh language.

In the endings of possessiveness to persons and numbers, features are not observed.

As it's known, suffixes are divided into suffixes, with the help of which nouns are also produced from the noun, and suffixes, with the help of which other parts of speech are produced. We found that of the suffixes that produce a noun from a noun, only the suffix -kek is found in the dictionary and in the Kazakh language. In the dictionary of suffixes that produce a noun from other parts of speech, there are only 42 (with different sound variations), 16 of which in the modern Kazakh language (-gish, -ek, -q, -lyq, -lik, -ma, -maq, -raq, -ik, -siz, -tyq, -shy+lylyk, -yq, -im, -ish, -khana) perform grammatical functions.

Of the 25 suffixes (-gach, -dyr, -di, -ek, -er, -qa+ra, -qach, -lú ,-lúk, -lyq, -raq, -ry, -suz, -tyr, -ti, -uq, um, -chaq, -chy, -shy, -y, -yq, -ym, -i), of adjectives, found in the dictionary, only 11 function in the Kazakh language (-dy, -ek, -er, -lyq, -raq, -syz, -shy, -y, -yq, -ym, -i). Most adjective suffixes that are not found in the modern Kazakh language are sound variations (-lúk, -suz, -um, -chy), and the comparative suffix of the adjective -raq is noted in the dictionary and in the modern Kazakh language.

There are 9 suffixes of derivative numerals (-mysh, -inchi, -nchi, -lúk, -lyq, -lik, -chi, -ik, -ish). Among them in the modern Kazakh language there are such as -lyq, -lik. Such a relatively small number of suffixes, of course, can be connected with the fact that during the compilation of the dictionary there were also errors of scribes and specific rules of spelling and orthoepy, which also introduced their own peculiarities. Nevertheless, we can say with a certain degree of confidence that all suffixes of the numeral with phonetic changes that occur in the dictionary are not alien to our modern Kazakh language.

As we know, in all languages of the world the richest and most complex part of speech in terms of grammatical categories is the verb. So, analyzing auxiliary morphemes of this part of speech, we divide them into suffixes that produce a verb from a verb, and suffixes that produce a verb from other parts of speech. Auxiliary, i.e. formative morphemes producing verb forms from the verb form the participles, indefinite form of the verb, pledge of the verb, type of the verb, negative form of the verb. For example, in the Zamakhshari dictionary, the number of morphemes of this kind that produce morphemes from other parts of

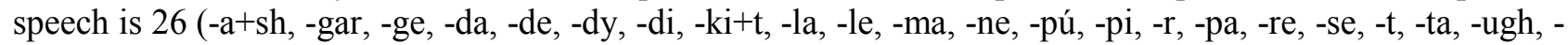
uq, -i, -ik, -ir, -it), half of which, namely 11 (-da, -de, -dy, -di, -la, -le, -ma, -i, -iq, -ir, -it) to this day, have a grammatical meaning and is actively functioning. All participle affixes - and there are 6 of them (-gan, gen, -qan, -ken, -kun, -mek), fixed in the dictionary, except for the affix -kú $\mathrm{n}$ are used in the Kazakh language. Auxiliary suffixes of participles (-a, -e, -i, -ei, -p, -un, -yp, -ip - 8 suffixes), except for -ei, -un we can find in the modern Kazakh language. The indefinite form of the verb, which is expressed through the suffix - $\mathrm{u}(-\mathrm{u})$, in the language units represented in the medieval material, is attached to the root in the form gú, -ǵu, -ki, -ku, -qu, i.e. through the infixes g, ǵ, k, q, applied depending on the last sound or syllable of the root. This feature is mainly characteristic of the Karluk and Oghuz groups of languages. Forms expressing the negative form of the verb, -ma, -me, -s - are the same in the dictionary and in the modern Kazakh language.

In the Kazakh language, verbs are divided into verbs in the form of a reflexive, causative, passive and reciprocal voice. In the dictionary, as in the Kazakh language, the only suffix -n of the reflexive voice is fixed. There are 15 suffixes of causative voice in the dictionary (-gúz, -dúr, -ker, -kúr, -qýz, -qýr, -n, -t, -týr, túr, -ýr, -úr, -yn, -yt), of which in the Kazakh language with phonetic changes occur -gúz, -dúr, -qýz, -týr, túr, and with a complete sound match suffix -t. Suffixes of the passive voice -yl, -il of the Kazakh language in the dictionary found in such variations as -ar, -al, -ýl, -úl, -yl, -il, and the suffix -s of the reciprocal voice of the Kazakh language in the dictionary occurs in the following pronunciation forms: - sh, -esh, ýsh, -úsh, -ysh, -ish, -ch.

It is worth noting that the attachment of suffixes of the passive voice to the root of the word occurs through infixes -a, -ý, -ú, selected depending on the sound composition of the last sound or syllable of the word, and the suffixes of the reciprocal voice-through infixes - e, -ý, -ú.

Thus, summing up the analysis of auxiliary forms of formation of the verb voices, we can say that the number of such forms in the dictionary is 29, and in the Kazakh language-4. Quite a large number of auxiliary forms that are present in the Zamakhshari dictionary, and causes our research interest. As we understand, 
such a high quantitative index of auxiliary forms is due primarily to the fact that the dictionary is a collection that includes a number of dialects and dialects of Turkic tribes.

Moving on to the analysis of the verb mood category, we note that it is divided into the imperative mood, the subjunctive mood, and the indicative mood. Suffixes of the imperative mood that occur in the dictionary are - - gil, -gin, -sýn, -sún, -syn, -t, they are partly reflected in the Kazakh language - - gin,syn, -t; of the suffixes of the subjunctive mood that we have isolated in the dictionary (-gai,-z), only one occurs in the Kazakh language -ǵa1; suffixes of conditional mood in the dictionary and in Kazakh are unchanged - -sa.

Past tense suffixes of the verb that we found in the dictionary, - -d, -i, - mysh, -mish, -ýn, they are also found in the Kazakh language - -di, -mysh, -mish, and the suffixes of the future tense - -er, -z, -maq, -mek, -r, -ýr, -er, we have marked in the dictionary in the Kazakh language the same - — r, -er, -maq, mek.

Thus, the Zamakhshari dictionary «Muqaddimat al-adab» recorded 99 suffixes of the verb, of which 42 suffixes still retain their functions in the Kazakh language and serve to form grammatical forms and grammatical meanings. This once again proves the historical one-root relationship between groups of Turkic language groups, such as Kipchak, Oghuz, and Karluk, and the features and differences of each of them are both the result of this dynamic change and an argument in favor of it.Zamakhshari's work is very rich in adverb suffixes: -ge, -ǵy, -da, -de, -dýz, -dúz, -e+l1, -ki, -le, -lyq, -ik, -ch, -cha, -che, -chýq. The total number of them in the dictionary is 15 , of which 7 have been preserved in the modern Kazakh language: -ǵy, -da, -de, dúz, -ki, -le, -lyq.

The results of research by scientists suggest that the appearance of homonymy and polysemy in the language, first, is due to the limited number of sounds, and secondly, to the homogeneity of the affix or root of the word. This is why homonyms are the result of phonetic and graphic phenomena, and polysemy is the result of lexical and semantic phenomena. In order to determine the homogeneity or heterogeneity of the root of a word or affix, it is necessary to identify the time of creation of the monument of writing, determine its source language, the author and the originality of the text. The search for an answer to these questions still presents special difficulties and is often almost fruitless, since the monuments of writing are a legacy and were written several tens of centuries ago. These circumstances, as well as the fact that the spelling and orthoepic principles of the time do not coincide with modern requirements, make it difficult to draw conclusions about the sound and syllabic compositions of words. For example, spelling and pronunciation in a dictionary of words «kónúl», «iúgúr», «iýmýr», «iolýǵ» does not match the spelling of the modern Kazakh language. The same applies to the entire lexicology, morphology, and syntax of the dictionary material. azZamakhshari wrote almost the same thing about the dictionary «Mukaddimat al-adab» in his eponymous article by the famous Turkologist Najip E. N., who, based on the analysis of lexical and grammatical notes by Poppe N. N., managed to list and point out some shortcomings of the work of the first researcher of the Zamakhshari dictionary in 1938 [6:125-127].

Consideration of homonymous and polysemantic affixes makes it possible to determine the following: first, it is not always possible to distinguish them in the etymological aspect, and secondly, to investigate in comparative historical terms the homogeneous and heterogeneous affixes of modern Turkic languages, including the Kazakh language. We can only observe the dynamics of their changes, i.e. the expansion or contraction of their grammatical functions.

We will verify this by analyzing several affixes as an example:

1) the affix -a performs the functions of both word-forming and form-forming suffixes. The affix-a has 3 grammatical meanings and can act as: an adverbial suffix (as-a-dar, ait-a-dur), a word-forming adverb suffix from a verb (yash-ur-a-zhasyryn), a word-forming verb suffix from a noun (yash-a, yashyn-anayzagaidyn zharkyldauy). All 3 grammatical meanings of the suffix -a are used both actively and passively in modern Kazakh;

2) the affix-ar in the dictionary functions as a formative suffix, has 2 grammatical meanings and acts as: the suffix of the passive voice (ag-ar, at-ar, yyg-ar) and the suffix of the future participle (ach-ar, bar-ar). The suffix -ar is active in the modern Kazakh language;

3 ) the affix -ge, being both the ending and the suffix, has 3 grammatical meanings. For example: the ending of the dative case -ge (belg-ge, egin-ge-iyqqa - to the shoulder) is found in the dictionary, and although etymologically the end of the dative case, it can also act as a suffix of the adverb producing them from the nominal parts of speech (bir-ge) and from the verb. In the modern Kazakh language, this affix has turned into either a passive or a dead suffix (el-ge-di-eledi, esirge-gen); 
4) the suffix -gen has the following grammatical meanings: the participle suffix (egil-gen, esir-gen); suffix of a noun that produces it from a numeral (yeti-gen — jeti qaraqshy zhuldyzy — Star Big Dipper; yetigen - jetinin biri - one seventh part). In the modern Kazakh language, the suffix -gene in the last indicated grammatical function exists only as a de-etymologized suffix.

5) the affix - $d a$ was used as a single form in 4 grammatical meanings. They are: ending of the local case (aqsham-da, iapan-da) from a historical point of view, suffix that forms an adverb (iol-da), suffix that forms a verb from a noun (abad-da, an-da-ońda, baiqa), a suffix that forms an adverb from an adverb (astydaki), that is, it performs the functions of a suffix and affix. In addition, an affix -da is used to form words, such as complex affixes, an adjective with a suffix that makes an addition to the dative case (1er-da-ǵy), the suffix of the verb and the suffix of participle (an-da $+i-$ ańdaǵyn, baiqaǵyn), suffix that forms a prefix from a noun and is combined with a common verb suffix (iol-da-sh);

6) the affix -de as the suffix of the local case (beshik-de, edish-de - ydysta), although historically it's a suffix of the local case, as the suffix that produce an adverb (erte-de), used as the suffix that produce a verb from a noun (belgú-de-di - belgiledi, tańbalady). its difference from the affix -da is that derived verbs create an adverb (kel-úr-de), performs the function of the dative case (iúrú-mek-de - júrmekke asyqty). A complex addition contains only the functions of an adjective connecting a noun with a local case(kól-deki, iúzin-de-ki);

7) the suffix -dur gives grammatical meaning of III person of personal ending (a1t-a-dýr, 1on-adýr), causative suffix (az-dýr, as-dýr);

8) the addition - $d y$ performs the function of accusative (aq-dy), personal endings (a1yb-la-dy, být-rady) and the function of the suffix that produces a verb(ar-dy);

9) the suffix -dyn performs the function of 2 cases: first used with the suffix of possessive case form -dyn (adab-dyn, 1a1-dyn), the second is ending of the outgoing case(bihýsh-lyq-dyn — sezbestikten, aǵryqlyqdyn - aýrýlyqtan, telbe-lik-din - esýastyqtan).

10) grammatical function of - di was used widely than of -dy. For example, -di performs the function of personal ending (ev-le-n-di, en-di - tústi), ending of accusative case (er-di), suffix that produces a verb from an adjective (berke-di), also grammatical meanings of the past simple suffix (eg-di — idi, eg-il-di), and the suffix that produces an adjective from a noun (es-di - esti);

11) the suffix - ek has characteristics of the suffixes that produce a noun from a verb (ból-ek), and produce an adjective from an adjective (ek(g)i-z-ek). As we know, researchers of historical grammar of the Turkic languages have proved that there were plural forms such as $-t$ and $-z$, except -lar (- ler), - dar (- der), and tar (- ter). We can speculate some thoughts about the affix $-Z$ in the composition of the derivative morpheme egizek. It is clear that the root of the word is -eki, affix - $z$ added to it gives the pairing value, and that this form (egiz) is actively used in Turkish languages. The word egizek, which is used though rarely, (Toǵyzaq, that is used in the name of man), that suffixes such as -ek (-aq) produce an adjective from an adjective, that the plural meaning of $-\mathrm{Z}$ is old and it has turned into a suffix that creates an adjective, and since the meaning of the adjective was substantivized, suffix -ek is added to the word egiz and an adjective is obtained (to the word togyz suffix -aq). In Turkic languages, including Kazakh, the word from the sound $-\mathrm{z}$ does not begin or end. The sonorous consonant sound $-z$ from the plural ending function was subjected to contraction with the roots of words. For example, name words such as we, you, eye, jalǵy-z, ek(g)i-z, toǵy-z, oty-z, alpy-s(z), jetpi-s(z), jú-z words in numeral meaning and numerals;

12) the suffix -er adds to the word the grammatical meaning of the suffix of the participle of the future tense (kel-er) and the suffix that creates an adjective from a noun (es-er);

13) the suffix - $k i$ has 2 grammatical meanings in a simple form: suffix of the indefinite form of the verb (kúr-ki-re+ki — kúrkireýi), suffix that produces an adverb from an adverb (astyda-ki, erte-ki — ertegi), in the compound form also has 2 grammatical meanings: a suffix that makes a verb from an interjection (kúr+ki+re-ki - kúnniń kúrkireýi), as part of a compound suffix that makes a verb from a noun(bir+ki+t-ken - ballanǵan);

14) the suffix -qýr performs functions of a causative (az-qýr-dy), of suffix that produces a noun from a verb (1am-qur — jańbyr: 1am — jamylý, jabý);

15) the affix -la performs only suffix functions, i.e. word-forming, in the category of simple suffix: makes a verb from a neutral word(1oq-la), a verb from an adjective (aǵyr-la, 1ah-shy+la-dy, 1aldýz+la-ǵan), a verb from a noun (1aǵ+la-dy — ma1lady, rashyn+la-dy — na1zaǵa1 oinady). As part of a complex suffix $(-\mathrm{la}+\mathrm{sh})$, it comes and performs the functions of a reciprocal voice, creating a verb with a noun. 
16) the suffix -le performs 4 functions as a simple suffix, 4 as a compound suffix, that is, an active and a rich addition to the meaning that form the basis of 8 grammatical meanings. This suffix in a simple form: makes a verb from a noun (eier-le-di — erttedi, iún-le-di — júndedi, qaýyrsynyn juldy), a verb from a derived noun (ber-im+le-di-ler), an adverb from a numeral, a verb from an adjective (erke+le-di), in a compound form: to the suffix that produces a verb from a noun adding the suffix of the reflexive voice (-men, -pen: bir-le+n), to the suffix that produces a verb from a noun adding the suffix of the reflexive voice (1úk-le+n-mish - ú1melegen, kónúl-le+n-di), to the suffix that creates a verb from a number we add the ending of possessiveness, then to it ending of accusative (ek-e-le+si-ni - ekeýin) and to the suffix that makes a verb from a noun add the suffix of reciprocal voice (beg-le+sh-ti);

17) the suffix -lúk: affix that produces an adjective from a noun (belgú-lúk, lún-lúk — tústes), a noun from a noun(1egú-lúk — tamaq, aýqat);

18) hard non-labialized version -lyq of labialized suffix -lúk gives 5 grammatical meanings: an adjective from a noun (1aǵ-lyq, at+lyq-lar - attylylar), a noun from a verb (aǵry-lyq, bil-me-s-lyq), a noun from a noun (dost-lyq, dýshman-lyq), an adverb from a noun (elchi-lyq, dýzah+lyq-lar-nyń), a noun from an adjective (1aqshy-lyq);

19) soft non-labialized version -lik of the labialized suffix -lúk makes a noun from an adjective (biiiklik), a noun from a verb (bil-mek+lik), a noun from a noun (djebe+lik-ler — nazashylar, em-lik, es-lik), derived numeral (el-lik — elý);

20) the affix -ma: makes a noun from a verb (1ar-ma — jarma dán, jem), a verb from a noun(1a+ma$\mathrm{dy})$, and the negative form of the verb (att+ma-dy);

21) - maq: produces a noun from a verb (1ar-maq), and participle of the future attainment time (aǵyrla+maq, a1t-maq);

22) One feature of the suffix -mek from its hard version - maq is that it does not have the function of making a verb from a noun. This suffix is actually a suffix of participle (1úgúr + mek — júgirgen), future achievement tense (ber-mek, bút-ker+mek).

23) The suffix (-) men refers to complex categories because in Turkish languages their historical functions are very different. For example the unit -men: personal pronoun, copulative and the case ending. Forms other than classification pronouns are subject to sound changes in context (copulative: men, pen, ben, case ending: -men, -pen, -ben). The presence of a category of main morpheme, auxiliary morpheme, and additional morpheme within a single language unit makes it difficult to identify the causes and consequences of these single-content and formal relationships and similarities. For example, the change of the classification pronoun (men bara-myn) was not considered in the grammar of Akhmet Baitursynov as a case form, but the question of what cause-and-effect relations have in etymological, diachronic relation with the first two conjunctions.

24) the suffixes -mysh, -mysh have the services of making cardinal numbers (alt-mysh, -1et-mish), and past participles (ach-yl-mysh chechek — ashylǵan gúl, 1esh-il+mish — sheshilgen);

25) - ny, -ni performs the function of accusative case endings (aǵryq-ny, bash-ny, aých-ni, ev-ni, bergen-ni), (baha-shy-ny, 1ahshy-lyǵ-y+ny). These are characteristic of Karluk languages; niń);

26) Affixes -nyń, -niń are used only in the function of the genitive case (a1aq-nyń, být-nyń, ev-niń, eki-

27) The suffix - $r$ makes a verb from a noun (belgú-r-t-mek), a verb from an adjective (eski-rdi), participle of future tense (1asa-r - túzetý);

28) - raq: suffix of the comparative degree of the adjective of the modern Kazakh language (asty-nraq, 1aman-raq) and historically dead suffix(1ap-raq, top-raq);

29) -re is the suffix that made a verb from an interjection (kúk-re-di — kúrkiredi), a verb from a noun;

30) -sún - suffix of the verb of imperative mood (ber-sún), suffix that produces a noun from a verb (búrke-sún);

31) -syz performs the functions of creating an adjective from a noun (1amǵýr-syz, aǵryq-syz), and an adjective from a neutral word (10q-syz);

32) $-s y$, -si can be attached to a word ending in both a vowel and a consonant, any case endings that join this ending can begin with any sound (ata-sy-ǵa, dýa-sy-qa, dýǵa-sy-na, 1aqa-sy-ny).

33) $-t$ as a simple affix performs three, as a compound affix two functions. A simple affix: suffix of the causative voice (ada+t-ty-júdetti, eri+t-ti), the short form of personal ending of the III person (bar$\mathrm{a}+\mathrm{t}$ ), suffix that makes a verb from a noun (el-t: el-qol, elt — qolǵa alý; el+t-ti — qolǵa alyp aparý). Compound affix: $-\mathrm{t}+\mathrm{qa}$ makes a verb from an adjective (1ým-ýr $+\mathrm{t}+\mathrm{qa}),-\mathrm{t}+(\mathrm{t}) \mathrm{i}($ berk-it $+\mathrm{i}$ — bekitti, berik etti); 
34) - ty, -ti personal ending (art-ty, ek-ti), and suffix that produce an adjective from a noun (es-ti);

35) $-y$ r can be the suffix of participle of the future tense (ait-yl+ýr), or the suffix causative voice (as+ýr-dy);

36) -ýq makes an adjective from a verb (ash-ýq, 1ez-ýq, 1ar-ýq), a noun from a verb (1ap-ýq — jabý, kórpe, 1yt-ýq - kiik jataǵy), a verb from a noun (1ol-ýq), and the last word formation in the modern language is not classified into the main, auxiliary morpheme;

37) -úk in a simple form makes a noun from a verb (ból-úk), in a compound form produces a noun (kóm-úl-dúr+úk);

38) -úl in both simple and compound form the suffix of the passive voice (bók+úl-di), (kóm+úldúr-úk);

39) The originality of the suffix -úm that it's firstly suffix that makes a noun from a verb (kór+úm-lúk - kórikti, kórim eken, kúl+úm-sún-di — myrs etti, miyǵynan kúldi, kúl+úm-si-di — kúlimsiredi), then forming the basis of the word (kór-úm, kúl-úm), then makes an adjective(kórúm-lúk — kórikti), or verb anew (kúlúmsún — myrs etý, kúlúm-si — kúlimsiredi);

40) Although the suffix - $u$ r is the sound variation of - yr, -ir, -ýr, and its functions are similar with the suffixes of future tense participle (kel-úr, kóch-úr), and causative voice (bit-it+úr-di), there is a feature in the function of making a noun from a verb(kóm-úr);

41) The main feature of the -che suffix is that it performs the function of generating the word, not converting: it does the addition (de-gín-che — deın), the addition of the noun (gadjem-che - parsysha), the component of the common suffix and the suffix (eg-ch + e - 1yqtasyp). - evaluate the general semantics of the -che suffix 3rd function - describing the state of the substance, that is, giving it a superscript value;

42) Although the meanings of the -chýq suffix are similar to the -shak, -shek suffixes in the modern Kazakh language, they are a synonym for the Karluk languages in this phonetic form. For example, it has two meanings: makes an adverb from an adjective (1ar-ým+chýq - jartyla1, shala), a verb from an adjective (býl-ǵan+chýq — bylǵanysh);

43) Although the -chy and - chi suffixes are soft-hard sound variants, the hard -chy suffix has a wide range of functions. This is evidenced by the -chy suffix being used in the dictionary material in 5 meanings. They are: suffixes that make a verb from a noun (ait-ý+chy, al-ǵý+chy), ordinals (alty-n+chy), a noun from an adjective (1alǵan-chy), a noun from a noun(1aǵ-chy — ma1 jasaýshy, 1a1-chy-sadaqshy), an adjective from a verb (1ah-chy - jaqsy). And in the dictionary materials there are 3 meanings of soft -chi suffix: makes a noun from a noun (bóz+chi, bit-ik+chi, el-chi), a noun from a verb(ebedek-chi, eshik-chi, keme-chi), suffix of subjective evaluation (kesh-chi — keshirshi);

44) Auxiliary morpheme -shy is used as a phonetic complex, as a third person form of possessiveness in the Kazakh language (baha + shy-ny), as a suffix creating an adjective from the verb (1ah-shy);

45) Affix $-y$ is used as the suffix making an adjective from a noun (arab-y), ending of III person possessiveness (aǵyz-y, 1azýq-y). It is noticeable that after the end of possessiveness, the direct connection of case endings expands (bash-y+da, boǵaz-y+qa, bas-y+qa, 1arýq-y-dyn) ;

46) Multifunctional affix $-y q$ actually makes name words: a noun from a verb (a1yr-yl+yq-y), an adjective from a verb (ach-yq, 1yr-yq);

47) $-y m$ is the suffix that makes an adjective from a verb (1ar-ym - jarty, ortasy), has III person of the personal endings (1armaq-ym);

48) Affix - $y n$ appears in 4 variants: suffix of the causative voice(al-yn) and - yn in other 3 variants case endings added to the III form of possessiveness (1an-yn+da, dost-yn+dyn, 1azýq+yn-y);

49) Although the first meaning of the suffix -ysh is reciprocal voice (air-yl+ysh-ty-lar), second meaning is the suffix making a verb from a verb, and the story, at least, consists in combining, merging two actions, that is, turning into a common cause;

50) 3 meaning of the affix $-i$ making an adjective from a noun (arab-i), a verb from a noun (bit + i-di: bit — hat, biti — jazý, bitidi — jazdy, jazyp bitirdi), other 3 forms are give only one meaning (elik-i+di — qolyn; bel-i+ge; elik-i-ge; bir-i+din);

51) The affix -ik performs the only suffixal function: makes a noun from a verb (ból-ik), a noun from a noun (bit-ik - jazý), a verb from an adverb(kech+ik-di);

52) -il performs the function of a passive voice (eg+il-gen - iilgen), and of a suffix that creates a verb from a noun (kún+il-e-di — kúndedi, qyzǵandy); 
53) This ending $-i$ has its own characteristics in comparison with the ending $-i$ mentioned in the 50th position. The peculiarity is manifested in the declination of nominative words after the ending of possessiveness. For example, to a substantive numeral case endings are added already with the possessiveness of III person (bir-i-n, bir-i-n-i, bir-i-n-ge, bir-i-si-ge). In the modern Kazakh language, either the initial form or the possessive form of case endings are added to the nominal or substantive word. The initial and possessive forms are not added at the same time, and the addition of two possessive or two case forms contradicts both the law of logic and language rules. The reason is clear;

54) affix -in used as part of a compound: ordinal suffix (besh-in+chi, ek-in+chi), the endings of the possessive form and the dative case are consecutive (ev-in+ge);

55) -ish as a simple suffix has three meanings: reciprocal voice (bit+ish-ti-ler), producing a noun from a verb, (kel-ish - barys-kelis), and a noun from a noun (jem-ish), as a compound suffix produces reciprocal voice from a verb, then participle (kón-ish+ken).

56) -ar used as form-forming suffix. This suffix has 2 grammatical meaning: passive voice suffix(aǵar, at-ar, 1yǵ-ar) and participle of the future tense(ach-ar, bar-ar). These suffixes are now used as active suffixes in the Kazakh language;

57) the affix -ge, being both the ending and the suffix, has 3 grammatical meanings. For example: the ending of the dative case -ge (belg-ge, egin-ge-iyqqa - to the shoulder) is found in the dictionary, and although etymologically the end of the dative case, it can also act as a suffix of the adverb producing them from the nominal parts of speech (bir-ge) and from the verb. In the modern Kazakh language, this affix has turned into either a passive or a dead suffix (el-ge-di-eledi, esirge-gen);

58) the suffix -gen has the following grammatical meanings: the participle suffix (egil-gen, esir-gen); suffix of a noun that produces it from a numeral (yeti-gen — jeti qaraqshy zhuldyzy — Star Big Dipper; yetigen - jetinin biri - one seventh part). In the modern Kazakh language, the suffix -gene in the last indicated grammatical function exists only as a de-etymologized suffix.

59) the affix - $d a$ was used as a single form in 4 grammatical meanings. They are: ending of the local case (aqsham-da, iapan-da) from a historical point of view, suffix that forms an adverb (iol-da), suffix that forms a verb from a noun (abad-da, an-da-ońda, baiqa), a suffix that forms an adverb from an adverb (astydaki), that is, it performs the functions of a suffix and affix. In addition, an affix - da is used to form words, such as complex affixes, an adjective with a suffix that makes an addition to the dative case (1er-da-ǵy), the suffix of the verb and the suffix of participle (an-da $+i-$ ańdaǵyn, baiqaǵyn), suffix that forms a prefix from a noun and is combined with a common verb suffix (iol-da-sh);

60) the affix -de as the suffix of the local case (beshik-de, edish-de - ydysta), although historically it's a suffix of the local case, as the suffix that produce an adverb (erte-de), used as the suffix that produce a verb from a noun (belgú-de-di — belgiledi, tańbalady). its difference from the affix -da is that derived verbs create an adverb (kel-úr-de), performs the function of the dative case (iúrú-mek-de — júrmekke asyqty). A complex addition contains only the functions of an adjective connecting a noun with a local case(kól-deki, iúzin-de-ki);

61) the suffix -dýr gives grammatical meaning of III person of personal ending (att-a-dýr, 1on-adýr), causative suffix (az-dýr, as-dýr);

62) the addition - $d y$ performs the function of accusative (aq-dy), personal endings (ayyb-la-dy, být-rady) and the function of the suffix that produces a verb(ar-dy);

63) the suffix -dyn performs the function of 2 cases: first used with the suffix of possessive case form dyn (adab-dyn, 1a1-dyn), the second is ending of the outgoing case(bihýsh-lyq-dyn — sezbestikten, aǵryqlyqdyn - aýrýlyqtan, telbe-lik-din - esýastyqtan).

64) grammatical function of - di was used widely than of -dy. For example, -di performs the function of personal ending (ev-le-n-di, en-di - tústi), ending of accusative case (er-di), suffix that produces a verb from an adjective (berke-di), also grammatical meanings of the past simple suffix (eg-di - idi, eg-il-di), and the suffix that produces an adjective from a noun (es-di - esti);

65) the suffix -ek has characteristics of the suffixes that produce a noun from a verb (ból-ek), and produce an adjective from an adjective (ek(g)i-z-ek). As we know, researchers of historical grammar of the Turkic languages have proved that there were plural forms such as $-t$ and $-z$, except -lar (- ler), - dar (- der), and tar (- ter). We can speculate some thoughts about the affix $-Z$ in the composition of the derivative morpheme egizek. It is clear that the root of the word is -eki, affix - $\mathrm{z}$ added to it gives the pairing value, and that this form (egiz) is actively used in Turkish languages. The word egizek, which is used though rarely, (Toǵyzaq, that is used in the name of man), that suffixes such as -ek (-aq) produce an adjective from 
an adjective, that the plural meaning of $-\mathrm{z}$ is old and it has turned into a suffix that creates an adjective, and since the meaning of the adjective was substantivized, suffix -ek is added to the word egiz and an adjective is obtained (to the word togyz suffix -aq). In Turkic languages, including Kazakh, the word from the sound -z does not begin or end. The sonorous consonant sound $-z$ from the plural ending function was subjected to contraction with the roots of words. For example, name words such as we, you, eye, jalǵy-z, ek(g)i-z, toǵy-z, oty-z, alpy-s(z), jetpi-s(z), jú-z words in numeral meaning and numerals;

66) the suffix -er adds to the word the grammatical meaning of the suffix of the participle of the future tense (kel-er) and the suffix that creates an adjective from a noun (es-er);

67) the suffix - $k i$ has 2 grammatical meanings in a simple form: suffix of the indefinite form of the verb (kúr-ki-re+ki — kúrkireýi), suffix that produces an adverb from an adverb (astyda-ki, erte-ki - ertegi), in the compound form also has 2 grammatical meanings: a suffix that makes a verb from an interjection (kúr+ki+re-ki — kúnniń kúrkireýi), as part of a compound suffix that makes a verb from a noun(bir+ki+t-ken - ba1lanǵan);

68) the suffix -qýr performs functions of a causative (az-qýr-dy), of suffix that produces a noun from a verb (1am-qur — jańbyr: 1am — jamylý, jabý);

69) the affix -la performs only suffix functions, i.e. word-forming, in the category of simple suffix: makes a verb from a neutral word (1oq-la), a verb from an adjective (aǵyr-la, 1ah-shy+la-dy, raldýz+la-ǵan), a verb from a noun (1aǵ+la-dy - ma1lady, 1ashyn+la-dy — naızaǵa oinady). As part of a complex suffix $(-\mathrm{la}+\mathrm{sh})$, it comes and performs the functions of a reciprocal voice, creating a verb with a noun.

70) the suffix -le performs 4 functions as a simple suffix, 4 as a compound suffix, that is, an active and a rich addition to the meaning that form the basis of 8 grammatical meanings. This suffix in a simple form: makes a verb from a noun (eier-le-di — erttedi, iúń-le-di — júndedi, qaýyrsynyn juldy), a verb from a derived noun (ber-im+le-di-ler), an adverb from a numeral, a verb from an adjective (erke+le-di), in a compound form: to the suffix that produces a verb from a noun adding the suffix of the reflexive voice (-men, pen: bir-le $+n$ ), to the suffix that produces a verb from a noun adding the suffix of the reflexive voice (1úkle+n-mish - úımelegen, kónúl-le+n-di), to the suffix that creates a verb from a number we add the ending of possessiveness, then to it ending of accusative (ek-e-le+si-ni — ekeýin) and to the suffix that makes a verb from a noun add the suffix of reciprocal voice (beg-le+sh-ti);

71) the suffix -lúk: affix that produces an adjective from a noun (belgú-lúk, lún-lúk — tústes), a noun from a noun (1egú-lúk — tamaq, aýqat);

72) hard non-labialized version -lyq of labialized suffix -lúk gives 5 grammatical meanings: an adjective from a noun (1aǵ-lyq, at+lyq-lar - attylylar), a noun from a verb (aǵry-lyq, bil-me-s-lyq), a noun from a noun (dost-lyq, dýshman-lyq), an adverb from a noun (elchi-lyq, dýzah+lyq-lar-nyń), a noun from an adjective (aqshy-lyq);

73) soft non-labialized version -lik of the labialized suffix -lúk makes a noun from an adjective (biiiklik), a noun from a verb (bil-mek+lik), a noun from a noun (djebe+lik-ler — naizashylar, em-lik, es-lik), derived numeral (el-lik — elý);

74) the affix -ma: makes a noun from a verb (1ar-ma — jarma dán, jem), a verb from a noun(1a+mady), and the negative form of the verb (ait + ma-dy);

75) - maq: produces a noun from a verb (1ar-maq), and participle of the future attainment time(aǵyrla+maq, ait-maq);

76) One feature of the suffix -mek from its hard version - maq is that it does not have the function of making a verb from a noun. This suffix is actually a suffix of participle (1úgúr+mek — júgirgen), future achievement tense (ber-mek, bút-ker+mek).

77) The suffix (-) men refers to complex categories because in Turkish languages their historical functions are very different. For example the unit -men: personal pronoun, copulative and the case ending. Forms other than classification pronouns are subject to sound changes in context (copulative: men, pen, ben, case ending: -men, -pen, -ben). The presence of a category of main morpheme, auxiliary morpheme, and additional morpheme within a single language unit makes it difficult to identify the causes and consequences of these single-content and formal relationships and similarities. For example, the change of the classification pronoun (men bara-myn) was not considered in the grammar of Akhmet Baitursynov as a case form, but the question of what cause-and-effect relations have in etymological, diachronic relation with the first two conjunctions.

78) the suffixes -mysh, -mysh have the services of making cardinal numbers (alt-mysh, -1et-mish), and past participles (ach-yl-mysh chechek — ashylǵan gúl, 1esh-il+mish — sheshilgen); 
79) - ny, -ni performs the function of accusative case endings (aǵryq-ny, bash-ny, aých-ni, ev-ni, bergen-ni), (baha-shy-ny, 1ahshy-lyǵ-y+ny). These are characteristic of Karluk languages; niń);

80) affixes -nyń, -niń are used only in the function of the genitive case (a1aq-nyń, být-nyń, ev-niń, eki-

81) suffix - $r$ makes a verb from a noun(belgú-r-t-mek), a verb from an adjective (eski-r-di), participle of the future tense (1asa-r — túzetý);

82) - raq: suffix of the comparative degree of the adjective of the modern Kazakh language (asty-nraq, 1aman-raq) and historically dead suffix(1ap-raq, top-raq);

83) -re is the suffix that made a verb from an interjection (kúk-re-di - kúrkiredi), a verb from a noun;

84) -sún - verb of imperative mood (ber-sún), suffix that produces a noun from a verb (búrke-sún);

85) -syz performs the functions of creating an adjective from a noun (1amǵýr-syz, aǵryq-syz), and an adjective from a neutral word (1oq-syz);

86) $-s y$, $-s i$ can be attached to a word ending in both a vowel and a consonant, any case endings that join this ending can begin with any sound (ata-sy-ǵa, dýa-sy-qa, dýǵa-sy-na, 1aqa-sy-ny).

87) $t$ as a simple affix performs three, as a compound affix two functions. A simple affix: suffix of the causative voice (1ada+t-ty-júdetti, eri+t-ti), the short form of personal ending of the III person (bar$\mathrm{a}+\mathrm{t}$ ), suffix that makes a verb from a noun (el-t: el-qol, elt - qolǵa alý; el+t-ti — qolǵa alyp aparý). Compound affix: $-\mathrm{t}+\mathrm{qa}$ makes a verb from an adjective (1ým-ýr $+\mathrm{t}+\mathrm{qa}),-\mathrm{t}+(\mathrm{t}) \mathrm{i}($ berk-it $+\mathrm{i}$ - bekitti, berik etti);-ty, - $t i$ perform the functions of personal endings (a1t-ty, ek-ti), makes an adjective from a noun(es-ti); dy);

88) $-y$ r can be the suffix of the participle of the future tense (a1t-yl+ýr), or a suffix of causative (as+ýr-

89) -ýq makes an adjective from a verb (ash-ýq, 1ez-ýq, ıar-ýq), a noun from a verb (1ap-ýq — jabý, kórpe, 1yt-ýq - kiik jataǵy), a verb from a noun (1ol-ýq), and the last word formation in the modern language is not classified into the main, auxiliary morpheme;

90) -úk in a simple form makes a noun from a verb (ból-úk), in a compound form produces a noun (kóm-úl-dúr+úk);

91) -úl in both simple and compound form the suffix of the passive voice (bók+úl-di), (kóm+úldúr-úk);

92) The originality of the suffix -úm that it's firstly suffix that makes a noun from a verb (kór+úm-lúk — kórikti, kórim eken, kúl+úm-sún-di - myrs etti, mıǵynan kúldi, kúl+úm-si-di — kúlimsiredi), then forming the basis of the word (kór-úm, kúl-úm), then makes an adjective(kórúm-lúk — kórikti), or verb anew (kúlúmsún — myrs etý, kúlúm-si — kúlimsiredi);

93) Although the suffix - $u r$ is the sound variation of - yr, -ir, -ýr, and its functions are similar with the suffixes of future tense participle (kel-úr, kóch-úr), and causative voice (bit-it+úr-di), there is a feature in the function of making a noun from a verb(kóm-úr);

94) The main feature of the -che suffix is that it performs the function of generating the word, not converting: it does the addition (de-gín-che — deın), the addition of the noun (gadjem-che - parsysha), the component of the common suffix and the suffix (eg-ch + e - 1yqtasyp). - evaluate the general semantics of the -che suffix 3rd function - describing the state of the substance, that is, giving it a superscript value;

95) Although the meanings of the -chýq suffix are similar to the -shak, -shek suffixes in the modern Kazakh language, they are a synonym for the Karluk languages in this phonetic form. For example, it has two meanings: makes an adverb from an adjective (1ar-ým+chýq — jartyla1, shala), a verb from an adjective (býl-ǵan+chýq — bylǵanysh);

96) Although the -chy and - chi suffixes are soft-hard sound variants, the hard -chy suffix has a wide range of functions. This is evidenced by the -chy suffix being used in the dictionary material in 5 meanings. They are: suffixes that make a verb from a noun (alt-ýtchy, al-ǵý+chy), ordinals (alty-n+chy), a noun from an adjective (1alǵan-chy), a noun from a noun(1aǵ-chy - ma1 jasaýshy, 1a1-chy-sadaqshy), an adjective from a verb (1ah-chy - jaqsy). And in the dictionary materials there are 3 meanings of soft -chi suffix: makes a noun from a noun (bóz+chi, bit-ik+chi, el-chi), a noun from a verb(ebedek-chi, eshik-chi, keme-chi), suffix of subjective evaluation (kesh-chi — keshirshi);

97) Auxiliary morpheme -shy is used as a phonetic complex, as a third person form of possessiveness in the Kazakh language (baha + shy-ny), as a suffix creating an adjective from the verb (1ah-shy);

98) Affix $-y$ is used as the suffix making an adjective from a noun (arab-y), ending of III person possessiveness (aǵyz-y, 1azýq-y). It is noticeable that after the end of possessiveness, the direct connection of case endings expands (bash-y+da, boǵaz-y+qa, bas-y+qa, 1arýq-y-dyn) ; 
99) Multifunctional affix $-y q$ actually makes name words: a noun from a verb (a1yr-yl+yq-y), an adjective from a verb (ach-yq, 1yr-yq);

100) $-y m$ is the suffix that makes an adjective from a verb (1ar-ym — jarty, ortasy), has III person of the personal endings (1armaq-ym);

101) Affix - $y n$ appears in 4 variants: suffix of the causative voice(al-yn) and - yn in other 3 variants case endings added to the III form of possessiveness ( $1 \mathrm{an}-\mathrm{yn}+\mathrm{da}$, dost-yn+dyn, 1azýq $+\mathrm{yn}-\mathrm{y})$;

Although the first meaning of the suffix $-y$ sh is reciprocal voice (arr-yl+ysh-ty-lar), second meaning is the suffix making a verb from a verb, and the story, at least, consists in combining, merging two actions, that is, turning into a common cause;

3 meaning of the affix $-i$ making an adjective from a noun (arab-i), a verb from a noun (bit+i-di: bit — hat, biti — jazý, bitidi — jazdy, jazyp bitirdi), other 3 forms are give only one meaning (elik-i+di - qolyn; bel-i+ge; elik-i-ge; bir-i+din);

104) affix -ik serves only as a suffix: produces a noun from a verb (ból-ik), a noun from a noun (bit-ik - jazý), a verb from an adverb (kech+ik-di);

105) - -il performs the function of a passive voice (eg+il-gen - iilgen), and of a suffix that creates a verb from a noun (kún+il-e-di — kúndedi, qyzǵandy);

106) This ending $-i$ has its own characteristics in comparison with the ending $-i$ mentioned in the 50th position. The peculiarity is manifested in the declination of nominative words after the ending of possessiveness. For example, to a substantive numeral case endings are added already with the possessiveness of III person (bir-i-n, bir-i-n-i, bir-i-n-ge, bir-i-si-ge). In the modern Kazakh language, either the initial form or the possessive form of case endings are added to the nominal or substantive word. The initial and possessive forms are not added at the same time, and the addition of two possessive or two case forms contradicts both the law of logic and language rules. The reason is clear;

107) affix -in used as part of a compound: ordinal suffix (besh-in+chi, ek-in+chi), the endings of the possessive form and the dative case are consecutive (ev-in+ge);

108) -ish as a simple suffix has three meanings: reciprocal voice (bit + ish-ti-ler), producing a noun from a verb, (kel-ish - barys-kelis), and a noun from a noun (jem-ish), as a compound suffix produces reciprocal voice from a verb, then participle (kón-ish+ken).

In summary: we can conclude that: 1) many suffixes that are not used in the modern Kazakh language differ only in phonetic composition, and their grammatical functions do not differ from the suffixes that we have isolated in the dictionary; 2) the Zamakhshari dictionary does not provide contextual examples in accordance with the genre of the work, so it is difficult to say whether the entire vocabulary of the Turkic dialects of that time is covered; 3 ) homonymous and multivalued auxiliary morphemes, i.e. multifunctional affixes, are those auxiliary morphemes that express at least two grammatical meanings; 4) most of the affixes available in the dictionary are used in modern Turkic languages, including Kazakh, some of them with phonetic changes perform functions both actively and passively; 5)in the historical aspect, the dynamics of the affixes' functioning can be observed and their changes retrospectively determined; 7) the laws of lingual and labial syngarmonism were not always observed, as a result of which there was a soft-hard assimilation of Turkic dialects. There are several reasons for phonetic disorders: a) in the Middle Ages, as it's known, the Turkic languages were integratively related to the Arabic and Persian languages, resulting in there is a influence of superstratic, interstratic and extralinguistic factors; b) this, on the one hand, once again confirms the hypothesis of the appearance of Karluk languages at the junction of Kipchak and Oghuz languages; c) an indicator of the existence of a Turkic language Union is that some affixes simultaneously have features of Kipchak, Karluk, and Oghuz languages; 8)The materials of the dictionary show that before the differentiation of Turkic languages into genetic branches, they had a common language basis.

\section{References}

1 Поппе Н.Н. Монгольский словарь «Мукаддимат ал-адаб». Ч. І. / Н.Н. Поппе. — М.-Л.: АН СССР, 1938. — 452 с.

2 Амирова Т.А. История языкознания: учеб. пос. / Т.А. Амирова. - М., 2010. — 241 с.

3 Шулежкова С.Г. История лингвистических учений: учеб. пос. / С.Г. Шулежкова. — М., 2008. — 217 с.

4 Березин Ф.М. История лингвистических учений / Ф.М. Березин. - М.: Высш. шк., 1975. - 312 с.

5 Жалмаханов Ш.Ш. Тіл білімінің тарихы / Ш.Ш. Жалмаханов. — Қарағанды: ҚарМУ, 1999. — 203 б.

6 Наджип Э.Н. Регионы и этапы формирования тюркских письменных языков и литератур / Э.Н. Наджип. Туркестан: Туран, 2007. - С. 125-127. 


\title{
А. Байниязов, М.Ә. Маретбаева, Ш.Ш. Жалмаханов, М. Жүсіпов \\ Әз-Замахшаридың «Мукаддимат әл-әдәб» (XIII ғ.) сөздігі мен қазақ тіліне ортақ көмекші морфемалардың фоно-морфо-лексикалық ұқсастықтары
}

\begin{abstract}
Мақалада түркі тілдерінің туыстық қатынастарының интеграциялық және дифференциациялық, тілдік одақ мәселелеріне тарихи лингвистикалық шолу жасалған. Авторлар өз ізденістерін түйіндей келіп, түркі ру-тайпаларының тілдік ұқсастықтары интеграцияның, ал олардың ерекшеліктері орта ғасырларда бөлінуінің, соның нәтижесінде қазіргі халықтар мен ұлттардың бастамасы болды деген пайымға келген. Ал тілдердің туыстығы мен туыстасуы, интеграциялық және дифференциациялық үдерістер, одан тілдік одақтардың пайда болуы - сыртқы факторлардың нәтижесі. XIII ғасырдағы Замахшари сөздігі мен қазақ тіліндегі омонимдік және полисемиялық қосымшаларды, атап айтқанда, септік, көптік, жіктік, тәуелдік жалғауларды, зат есімнің, сын есімнің, етістіктің жұрнақтарын салыстыру мен талдау олардың лексикасы мен аффикстер жүйесінің тектестігін дәлелдеген. Мақала авторлары ізденістерін тұжырымдай отырып, сөздік пен қазақ тіліндегі сөздердің дыбыстық, мағыналық және грамматикалық қызметтерінің қыпшақ, оғыз және қарлұқ тобындағы тілдерге тән екендігін анықтаған.
\end{abstract}

Кілm сөздер: тілдердің бірігуі мен бөлінуі, ішкі және сыртқы факторлар, тілдер туыстығын анықтаудың негізгі критерийлері, көмекші морфемалар, түркі тілдерінің қыпшақ, оғыз, қарлұқ және бұлғар топтары.

\section{А. Байниязов, М.А. Маретбаева, Ш.Ш. Жалмаханов, М. Джусупов}

\section{Фоно-морфо-лексическое сходство вспомогательных морфем словаря «Мукаддимат аль-адаб» (XIII в.) аз-Замахшари с казахским языком}

\begin{abstract}
В статье дан лингво-исторический обзор проблемы интеграции и дифференциации родства и сродства языков, в том числе рассмотрены особенности союзов. Исходя из проведенного лингвистического анализа, авторы приходят к мнению, что если наречия в языках разных родов и племен тюркского происхождения - результат интеграции тюркских языков, то разделение в средние века тюркских языков (современных национальных языков, какими являются казахский, киргизский, узбекский и т.д.) - результат деления тюркских языков на ветви, группы и подгруппы. В ходе работы авторы выявили интеграционные и дифференциационные процессы, родство и сродства языков и их объединение в один языковой союз, на возникновение которого повлияли экстралингвистические факторы. Анализ и сравнение омонимичных и полисемантичных вспомогательных морфем, а именно: падежных окончаний, окончаний множественного числа, принадлежности и склонения, суффиксов имени существительного, имени прилагательного, местоимений и глаголов словаря аз-Замахшари и казахского языка лишний раз доказывают историческую однородность лексики XIII века и современного казахского языка. В конце статьи авторами сделан вывод о том, что различия вспомогательных морфем в словаре «Мукаддимат аль-адаб» и казахском языке выражаются в фонетическом составе, а семантичные и грамматические функции морфем констатируют сходство и однородность языков, которые относятся к кипчакской, огузской и карлукской группам.
\end{abstract}

Ключевые слова: интеграция и дифференциация языков, внутренние и внешние факторы, основные критерии определения родства языков, вспомогательные морфемы, кипчакская, карлукская, огузская и булгарская группы тюркских языков.

\section{References}

1 Poppe, N. N. (1938). Monholskii slovar «Mukaddimat al-adab» [Mongolian dictionary «Mukaddimat al-adab»]. (Part I). Moscow; Leningrad: Akademiia nauk SSSR [in Russian].

2 Amirova, T.A. (2010). Istoriia yazykoznaniia [History of linguistics]. Moscow [in Russian].

3 Shulezhkova, S.G. (2008). Istoria linhvisticheskikh uchenii [History of linguistic teachings]. Moscow [in Russian].

4 Berezin, F. M. (1975). Istoria linhvistiheskikh uchenii [History of linguistic teachings]. Moscow: Vysshaia shkola [in Russian].

5 Zhalmakhanov, Sh.Sh. (1999). Til biliminin tarykhy [Linguistics history language]. Karaganda: KSU [in Kazakh].

6 Naazhip, E.N. (2007). Rehioni i etapy formirovaniia tiurkskykh pismennikh yazykov i literatur [Regions and stages of formation of Turkic written languages and literatures]. Turkestan: Turan [in Russian]. 